九州大学学術情報リポジトリ

Kyushu University Institutional Repository

Species Richness of Galling Arthropods in Manaus, Amazon and the Surroundings of the Iguassu Falls

Yukawa, Junichi

Tokuda, Makoto

Uechi, Nami

Sato, Shinsuke

https://doi.org/10.5109/2649

出版情報: ESAKIA. 41，pp.11-15，2001-03-31. Entomological Laboratory，Faculty of Agriculture， Kyushu University

バージョン :

権利関係 : 


\title{
Species Richness of Galling Arthropods in Manaus, Amazon and the Surroundings of the Iguassu Falls*
}

\author{
Junichi YUKAWA \\ Entomological Laboratory, Faculty of Agriculture, Kyushu University, Fukuoka, 812-8581 Japan \\ Makoto TokUdA, Nami UECHI and Shinsuke SATO \\ Entomological Laboratory, Graduate School of Bioresource and Bioenvironmental Science, Kyushu \\ University, Fukuoka, 812-8581 Japan
}

\begin{abstract}
We surveyed the species richness of galling arthropods in Iguassu and Manaus in 2000 and found at least 109 sorts of arthropod gall. The species richness of gallers that were sampled in Arizona and cerrado vegetation in Brazil has been supporting the microenvironment hypothesis, in which the galling habit is considered to be adaptive to dry areas. However, our data in Iguassu and Amazon, as well as the previous data in Indonesia and Japan, revealed that the galling species richness was considerably high in humid environments. Host plant species richness was considered to be an alternative explanation for the high galling species richness in humid areas.

Key words: species richness, galling arthropods, Amazon, Iguassu, humid environment, microenvironment hypothesis.
\end{abstract}

\section{Introduction}

The species richness of galling arthropods has been taken into consideration to explain the microenvironment hypothesis (Price et al., 1987), in which the galling habit is considered to be adaptive to dry areas. In northern Arizona, for example, galling species richness increased as the sites became drier and a similar trend was observed for the galls sampled from the relatively dry cerrado vegetation in Brazil (Price et al., 1987).

In contrast, Docters van Leeuwen-Reijnvaan \& Docters van Leeuwen (1926), who collected various sorts of gall chiefly in Java, Indonesia, pointed out that the abundance of galls was related to the number of plant species and galls were abundant in welldeveloped tropical rain forests consisting of many plant species. They also mentioned that midge galls were most abundant in stable vegetation under highly humid conditions.

In order to test the aforementioned two opposite explanations as to the adaptive significance of galling habit, we surveyed the species richness of galling arthropods in Iguassu and Manaus in 2000 on the occasion when we attended the 21 st International Congress of Entomology in Brazil. In this paper we report the result of our field survey and refer to an alternative explanation for the species richness of galling arthropods in humid areas.

\footnotetext{
* Contribution from the Entomological Laboratory, Faculty of Agriculture, Kyushu University, Fukuoka (Ser. 5, No. 59).
} 


\section{Materials and Methods}

In August 2000, we searched at random various plant species for insect and mite galls at the following census fields: the Iguassu Falls (Brazilian side and Argentinean side), Efejeniu Saures (Manaus, Brazil), and Rio Paraguquara (Manaus, Brazil) (Table 1). Because collection of organisms has been inhibited in the National Parks, our field survey was concentrated chiefly on the observation of gall appearance instead of collecting, rearing, and dissecting galls. At each census field, two of us searched for galls and the others recorded gall size, shape, coloration, galled portion, exit holes, etc. When we found leaf fold galls, leaf roll galls, or pouch galls, we carefully opened the galled portions and looked into organisms inhabiting the galls through a magnifying glass. After examining the galls, we closed galled portions as before. Based on the observation of gall appearance and gallers, we identified the respective gallers at the family, superfamily, or order levels. Unfortunately gall-bearing plants could not be identified.

Table 1. Localities of field survey and the time devoted to finding galls.

\begin{tabular}{|c|c|c|c|}
\hline Date & Census field & Location & $\begin{array}{c}\text { Time } \\
\text { (minutes) }\end{array}$ \\
\hline 25 Aug. 2000 & Iguassu (Brazilian side) & $\mathrm{S} 25^{\circ} 35^{\prime} \mathrm{W} 54^{\circ} 30^{\prime}$ & 50 \\
\hline 26 Aug. 2000 & Iguas & $\mathrm{S} 25^{\circ} 35^{\prime} \mathrm{W} 5$ & 60 \\
\hline 28 Aug. 2000 & Efejeniu Saures (Manaus, Brazil) & $\mathrm{S} 02^{\circ} 80^{\prime} \mathrm{W} 59^{\circ} 50^{\prime}$ & 60 \\
\hline 30 Aug. 2000 & Rio Paraguquara (Manaus, Brazil) & $\mathrm{S} 03^{\circ} 00^{\prime} \mathrm{W} 59^{\circ} 50^{\prime}$ & 135 \\
\hline
\end{tabular}

In order to adjust the intensity of different surveys, all field observation data were converted to time unit data (the number of sorts of gall found per hour by two persons, "TUD", hereafter). Then we analyzed the relationship between the time devoted to the field survey and the accumulated number of gall sorts, using the data in Rio Paraguquara. Based on TUD, we evaluated the species richness of galling arthropods at each census field. For the evaluation, we relied upon the assumptions that each gall morph is unique to a galling arthropod species and that galling arthropod species are specific to a single plant species (following Price et al., 1998).

Table 2. Sorts of insect and mite gall found in each census field.

\begin{tabular}{lcrrrc}
\hline & \multicolumn{5}{c}{ Census field* } \\
\cline { 2 - 6 } Galling arthropods & IB & IA & ES & RP & Total \\
\hline Cecidomyiidae & 3 & 13 & 20 & 33 & 69 \\
Eryophyoidea & 0 & 1 & 4 & 7 & 12 \\
Psylloidea & 0 & 1 & 3 & 3 & 7 \\
Thrips & 0 & 1 & 2 & 1 & 4 \\
Tephritidae & 0 & 0 & 1 & 0 & 1 \\
unknown & 5 & 1 & 2 & 8 & 16 \\
\hline Total & 8 & 17 & 32 & 52 & 109 \\
TUD** & 9.6 & 17.0 & 32.0 & 23.1 & 20.4 \\
\hline
\end{tabular}

*IB: Iguassu (Brazilian side), IA: Iguassu (Algentinean side), ES: Efejeniu Saures, RP: Rio Paraguquara.

**TUD: Time unit data (Sorts of gall found per hour by two persons). 


\section{Results}

A total of 109 sorts of insect and mite galls were found during the course of our field survey (Table 2; 8 and 17 sorts in Brazilian and Argentinean sides of the Iguassu Falls, respectively, 32 in Efejeniu Saures, Manaus, and 52 in Rio Paraguquara, Manaus). Among the 109 sorts, 69 were produced by Cecidomyiidae, 12 by Eriophyoidea, 7 by Psylloidea, 4 by Thysanoptera, 1 by Tephritidae, and 16 by unidentified gallers. At the surroundings of the Iguassu Falls (Brazilian and Argentinean sides), galls caused by Cecidomyiidae were most abundant and those by the others were hardly found. In Efejeniu Saures and Rio Paraguquara, galls by Cecidomyiidae were also most abundant and followed by those by Eriophyoidea, Psylloidea, and Thysanoptera.

Table 2 shows species richness expressed by TUD at each census field. TUD was higher in Manaus (23.1-32.0) than in Iguassu (9.6-17.0). The highest and lowest TUD were recorded in Efejeniu Saures (32.0) and in the Brazilian side of Iguassu (9.6), respectively. The average TUD was 20.4 throughout the field survey. In addition, when we were taking a cruise on a branch of the Amazon, we ( 2 persons) found, within 20 minutes, 9 sorts of gall produced on the trees growing along or in the river.

The accumulated number of gall sorts was significantly correlated with the time devoted to the field survey (Fig. $1: y=3.545+0.358 x, \mathrm{R}^{2}=0.993, P<0.0001, \mathrm{~N}=$ $6)$. This data indicates that more galls will be found when we devote more time to searching.

\section{Discussion}

Several evidences have been supporting the microenvironment hypothesis (Price et al., 1987), indicating that the galling habit is adaptive to dry areas. Fernandes et al. (1994) tested field patterns in mortality and survivorship of the gall fly Aciurina trixa Curran (Tephritidae) on Chrysothamnus nauseous hololeucus (Asteraceae) in the southwestern US. Aciurina trixa that colonized watered and fertilized plants suffered higher mortality than those that colonized control and stressed plants. From these results, they postulated that lower mortality caused by natural enemies and plant resistance in xeric habitats reinforced the galling habit, fostering speciation and radiation in harsh environments.

Based on the worldwide sampling data of insect galls, Price et al. (1998) argued strong association of galling species richness with scleromorphic vegetation, lower richness in moist sites relative to dry sites at the same latitude, and reduced richness in the wet tropics and cool temperate climates.

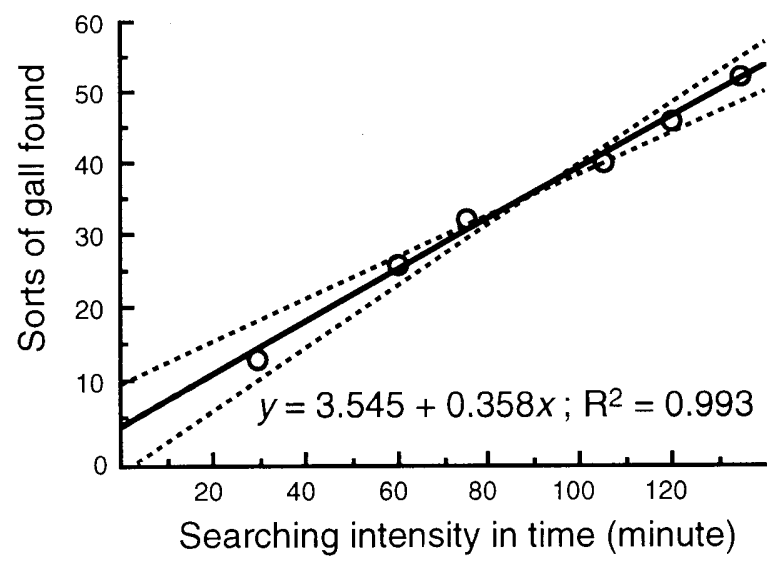

Fig. 1. Relationship between searching time and the number of sorts of gall found. Dotted lines indicate $99 \%$ confidence interval around the regression lines. 
In contrast, there are several examples indicating that the species richness of galling arthropods is relatively high under humid conditions. Besides the Javanese galling arthropods (Docters van Leeuwen-Reijnvaan \& Docters van Leeuwen, 1926), Yukawa and his colleagues collected many sorts of arthropod gall from tropical seasonal or rain forests at various localities in Indonesia; e.g., Peucang Island, Panaitan Island, and the Krakatau Islands (Yukawa \& Partomihardjo, 1997), Sulawesi Island (Yukawa et al., 2000), and Lombok Island, Bali Island, and Ujung Kulon (Yukawa et al., 2001). In addition, many sorts of midge gall have successively been found in Japan on various tree species under the canopy of broad-leaved evergreen forests where aerial humidity seems to be relatively high (Yukawa \& Masuda, 1996).

In the present survey, we also confirmed that species richness of galling arthropods was much higher in Amazon than in Iguassu (Table 2). Of course the surroundings of the Iguassu Falls were not so dry because of spray from the waterfalls, hence we found many sorts of gall at the surroundings. However, the species richness was relatively low, when compared with the species richness under highly humid conditions in the tropical rain forests of Amazon. In addition, we should emphasize that various galls were found on the trees growing along or in a branch of the Amazon.

The species richness of gallers that were sampled in Arizona and cerrado vegetation in Brazil (Price et al., 1987) well support the microenvironment hypothesis. However, our data in Iguassu and Amazon, as well as the data in Indonesia and Japan, requires an alternative explanation for the reason why the galling species richness becomes high in humid environments.

Wright \& Samways (1998) showed that the galling species richness was positively correlated with plant species richness both in mesic and in xeric sites (fynbos vegetation etc.) of the Cape Floristic Region, South Africa. Based on the data, they suggested that high plant species richness was an important factor in generating galling arthropod species richness. Thus plant species richness can be an alternative explanation for the high galling species richness in humid areas.

\section{Acknowledgements}

We wish to express our cordial thanks to Mr. Rinpei Inoue (Pulsar International Corporation, Tokyo) for his kind arrangement in the field survey. Our thanks are also extended to Dr. Keizi Kiritani (National Institute of Agro-Environmental Sciences, Tsukuba), Dr. Kunio Suzuki (Toyama University, Toyama), and other tour members to Amazon for their help in various ways.

\section{References}

Fernandes, G. W. \& P. W. Price, 1994. Life history, courtship, and mating behavior of the gall-forming Aciurina trixa (Diptera: Tephritidae) on Chrysothamnus nauseosus hololeucus (Asteraceae). Proc. Ent. Soc. Wash., 96: 301-307.

Docters van Leeuwen-Reijnvaan, J. \& W. M. Docters van Leeuwen, 1926. The Zoocecidia of the Netherlands East Indies.601pp. Batavia-Drukkerij de Unie.

Price, P. W., G. W. Fernandes \& G. L. Waring, 1987. Adaptive nature of insect galls. Envir. Ent., 16: 15-24.

Price, P. W., G. W. Fernandes, A. Christina, F. Lara, J. Brawn, H. Barrios, M. G. Wright, S. P. Ribeiro \& N. Rothcliff, 1998. Global patterns in local number of insect galling species. J. Biogeogr., 25: 581-591.

Wright, M. G. \& M. J. Samways, 1998. Insect species richness tracking plant species richness in a diverse flora: galling-insects in the Cape Floristic Region, South Africa. Oecologia, 115: 427-433. 
Yukawa, J. \& H. Masuda, 1996. Insect and Mite Galls of Japan in Colors. 826pp. Zenkoku Nôson Kyôiku Kyôkai, Tokyo. (In Japanese, with English explanations for color plates.)

Yukawa, J., K. Ogata, S. Kamitani, T. Ueno, T. Partomihardjo, S. Kahono \& P. O. Ngakan, 2000. A preliminary report of the field survey in 1999 on Sulawesi Island, Indonesia. Bull. Inst. Trop. Agr., Kyushu Univ., 22: 51-57.

Yukawa, J., K. Ogata, O. Yata, O. Tadauchi, S. Kamitani, S. Helwint, T. Partomihardjo, S. Kahono, P. O. Ngakan \& D. Yamaguchi, 2001. An Interim Report of the 2000 Survey of Entomofauna on Lombok Island, Bali Island, the Krakatau Islands, and in Ujung Kulon, Indonesia. Esakia, (41): 1-10.

Yukawa, J. \& T. Partomihardjo, 1997. Insect and mite galls collected from Peucang, Panaitan, and the Krakatau Islands, Indonesia. Tropics, 7: 141-152. 
